\title{
Purification and Properties of a Pectate Lyase in Erwinia aroideae
}

\author{
Shuwsei KamimiYa, Yoshifumi ItOH, Kazuo IZAKI \\ and Hajime TAKAHASHI \\ The Department of Agricultural Chemistry, Faculty of Agriculture, \\ Tohoku University, Sendai 980
}

Received December 20, 1976

\begin{abstract}
A strain of Erwinia aroideae produced an extracellular pectolytic enzyme under growth conditions with pectin or pectic acid as the inducer. This strain also produced a pectin lyase when nalidixic acid is added to a culture medium. The pectolytic enzyme produced under the growth conditions was purified approximately 40 -fold from the culture fluid by carboxymethyl cellulose and Sephadex G-75 gel column chromatographies. The purified enzyme was almost homogeneous on sodium dodecyl sulfate polyacrylamide gel electrophoresis, having a molecular weight of about 36,000 to 38,000 . This enzyme, with optimal activity at $\mathrm{pH} 9.0$ to 9.2 , produced reaction products which had a strong absorption at $230 \mathrm{~nm}$ indicating a lyase type of the reaction. The enzyme activity was markedly stimulated by calcium ion and completely inhibited by cobalt and mercuric ions and by ethylenediaminetetraacetate. Pectic acid or pectin with lower methoxyl content was a good substrate for this enzyme, while no significant activity was observed when pectin with higher methoxyl content was used as a substrate. It was concluded that the enzyme produced under the normal growth conditions is an endo-pectate lyase and differs from the pectin lyase induced by nalidixic acid.
\end{abstract}

It has been reported that various microorganisms produce several enzymes which attack pectin or pectic acid in different ways. In 1960, Albersheim et al. discovered the enzymatic degradation of pectin by a transelimination ("lyase") reaction rather than by the hitherto known hydrolysis. ${ }^{1)}$ It is now apparent that the major mechanism involved in breakdown of pectin and pectic compounds by enzymes of bacterial origin is by an elimination reaction which results in the formation of unsaturated products. On the basis of substrate specificity, these enzymes are classified into two groups, pectate lyase and pectin lyase. Pectin lyase, which attacks pectin but not pectic acid, has been demonstrated in fungi. ${ }^{2,3)}$ Pectate lyase, which attacks pectic acid more rapidly than pectin, appears to be widely distributed in bacteria. The bacterial pectate lyase have been found in species of Clostridium, ${ }^{4,5)}$ Xanthomonas, ${ }^{6,7)}$ Pseudomonas, ${ }^{8,9)}$ Bacillus, ${ }^{10,11)}$ and Erwinia. ${ }^{12,13)}$

Our strain of Erwinia aroideae produced an extracellular pectolytic enzyme under the normal growth conditions with pectin or pectic acid as the inducer. This strain also produced a pectolytic enzyme when the inhibitor of DNA synthesis such as nalidixic acid, mitomycin $\mathrm{C}$ or bleomycin is added to a culture medium. ${ }^{14}$ In previous papers, we have shown that the pectolytic enzyme induced by nalidixic acid was different from the enzyme formed under the normal growth conditions by the same organism ${ }^{15)}$ and that the former enzyme was an endo-pectin lyase. ${ }^{16)}$ The present paper describes the purification and properties of the enzyme produced under the normal growth conditions and demonstrates that the enzyme is an endo-pectate lyase.

\section{MATERIALS AND METHODS}

Enzyme and substrates. The pectin lyase induced by nalidixic acid was purified by the method described previously. ${ }^{10)}$ Pectin and pectic acid (Wako Junyaku Co., Ltd., Osaka) were washed three times with $70 \%$ (v/v) ethanol to remove soluble carbohydrates, but they still contained 20 to $30 \%$ of carbohydrates other than galacturonides on the basis of dry weight. Methylesterification of pectic acid was carried out according to the method of Manabe. ${ }^{17)}$ The degree of esterifica- 
tion of the substrates was measured by the method of Hirota. ${ }^{13)}$

Organism and cultural conditions. Erwinia aroideae (AMS 6082) was used throughout this experiment. The organism was pre-cultured at $30^{\circ} \mathrm{C}$ by shaking for $16 \mathrm{hr}$ in a nutrient broth ( $\mathrm{pH} \mathrm{6.8)} \mathrm{containing} 1 \%$ each of meat extract (Kyokuto Seiyaku Co., Ltd., Tokyo) and polypeptone (Daigo Eiyo Kagaku Co., Ltd., Osaka) and $0.5 \%$ of sodium chloride. After the culture, the cells were harvested and suspended in the basal medium, ${ }^{19)}$ which contained pectin, casein acid hydrolyzate, sodium glutamate and sodium aspartate. After incubation at $30^{\circ} \mathrm{C}$ for $6 \mathrm{hr}$ with shaking, cells were removed by centrifugation and the clear supernatant was used as the crude enzyme solution.

Assay of pectolytic enzyme. The assay of pectolytic enzyme, as determined by the decrease of viscosity of pectin substrate, was carried out by the method described previously. ${ }^{19}$ ) One unit was defined as the amount of enzyme which decreases the relative viscosity of the reaction mixture by 0.001 per min. The degree of viscosity reduction was calculated by the following equation; $\left(V_{t}-V_{s}\right) /\left(V_{0}-V_{s}\right) \times 100$. Where $V_{0}$, flow time in seconds of reaction mixture; $V_{t}$, flow time in seconds at each reaction time; and $V_{s}$, flow time in seconds of $10 \mathrm{ml}$ of water. The extents of cleavage of glycosidic bonds in pectin were determined by measuring the liberated aldehyde groups by the hypoiodite method. ${ }^{20)}$

Pectin lyase and pectate lyase activities were determined by a Hitachi 124 spectrophotometer. The reaction mixture was composed of $0.2 \%$ pectin or pectic acid, $0.05 \mathrm{M}$ Tris(hydroxymethyl)aminomethane- $\mathrm{HCl}$ buffer ( $\mathrm{pH} 8.0$ or 9.0 ) and the enzyme solution in a total volume of $10 \mathrm{ml}$. After incubation at $30^{\circ} \mathrm{C}$ for $20 \mathrm{~min}$, the enzyme was inactivated at $90^{\circ} \mathrm{C}$ for $10 \mathrm{~min}$. One unit was defined as the amount of enzyme which increases an optical density of 0.01 at $230 \mathrm{~nm}$ per min.

Sodium dodecyl sulfate (SDS) polyacrylamide gel electrophoresis. Electrophoresis was performed by the method described previously. ${ }^{10)}$

Sephadex G-15 column chromatography of enzymatic products from pectic acid. The purified enzyme, 5,000 units in viscosity reduction, was incubated with $0.2 \%$ pectic acid at $30^{\circ} \mathrm{C}$ for $4 \mathrm{hr}$. The reaction products were applied on a Sephadex G-15 column $(93 \mathrm{~cm}$ $\times 1.5 \mathrm{~cm}$ ) and eluted with $0.05 \mathrm{M}$ Tris(hydroxymethyl) aminomethane-HCl buffer ( $\mathrm{pH} \mathrm{8.0)}$. The substrate and products were assayed by the carbazole method, ${ }^{21)}$ using galacturonic acid as a standard.

Protein concentration. Protein concentrations were determined by the method of Lowry et al. ${ }^{22)}$ using bovine serum albumin as a standard.

\section{RESULTS}

\section{Purification of pectate lyase}

Unless otherwise stated, all the procedures for enzyme purification were carried out at $4^{\circ} \mathrm{C}$. The crude enzyme solution $(3000 \mathrm{ml})$ was diluted with 4 volumes of distilled water and applied onto a column of carboxymethyl (CM)-cellulose $(20 \times 2.5 \mathrm{~cm})$ previously equilibrated with $0.01 \mathrm{M}$ phosphate buffer ( $\mathrm{pH} 7,2$ ). After washing with the same buffer, the column was eluted with a linear gradient of sodium chloride from 0 to $0.5 \mathrm{M}$ in $0.01 \mathrm{M}$ phosphate buffer ( $\mathrm{pH} 7.2$ ) and fractions of $5 \mathrm{ml}$ were collected. As shown in Fig. 1, active fractions

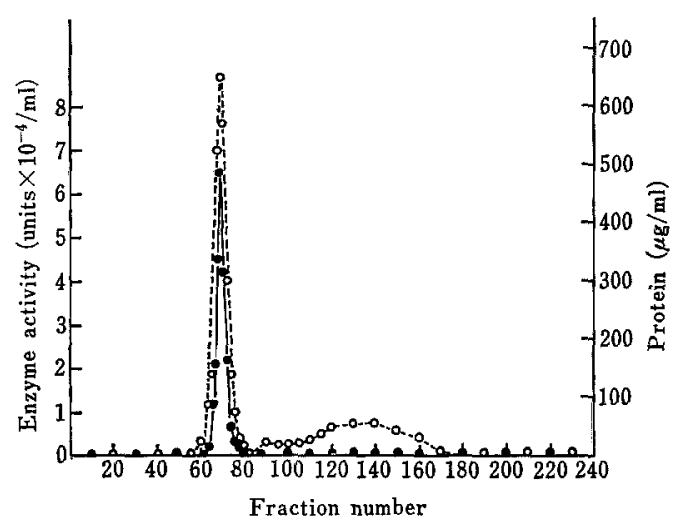

FIG. 1. Elution Profile of Pectolytic Enzyme on CMcellulose Column Chromatography.

- - activity of viscosity reduction (units/ml); $\mathrm{O}--\mathrm{O}$, protein concentration $(\mu \mathrm{g} / \mathrm{ml})$.

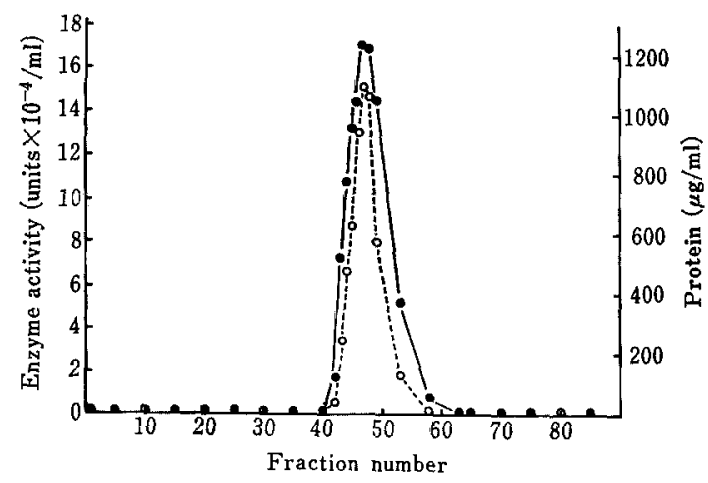

FIG. 2. Elution Profile of Pectolytic Enzyme on Sephadex G-75 Column Chromatography.

- - activity of viscosity reduction (units $/ \mathrm{ml}$ ); $\bigcirc--\bigcirc$, protein concentration $(\mu \mathrm{g} / \mathrm{ml})$. 
table I. Purification of Pectolytic Enzyme Formed under Normal Growth Conditions

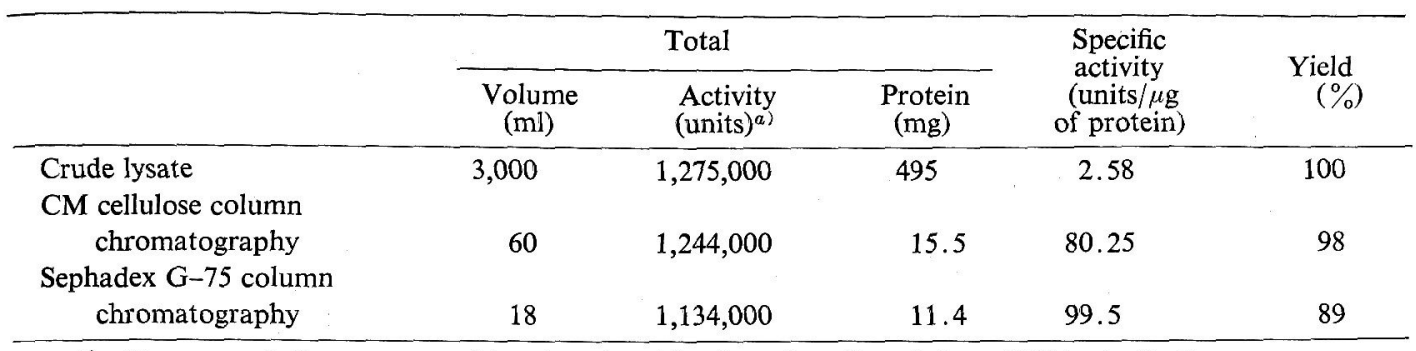

a) Enzyme activity was assayed by viscosity reduction of pectin substrate ( $64 \%$ esterified).

from No. 64 to $75(60 \mathrm{ml})$ were pooled and concentrated by ultrafiltration using a $\mathrm{G}-10 \mathrm{~T}$ membrane (Bio Engineering Co., Ltd., Tokyo). The concentrated solution $(2 \mathrm{ml})$ was loaded onto a Sephadex G-75 gel column $(93 \mathrm{~cm} \times$ $1.5 \mathrm{~cm}$ ) and eluted with $0.01 \mathrm{M}$ phosphate buffer ( $\mathrm{pH} 7.2$ ), and fractions of $2 \mathrm{ml}$ were collected. As shown in Fig. 2, fractions from No. 44 to $52(18 \mathrm{ml})$ were pooled and used as the purified enzyme in the following experiments. The purification and yield of the enzyme are summarized in Table I. The enzyme

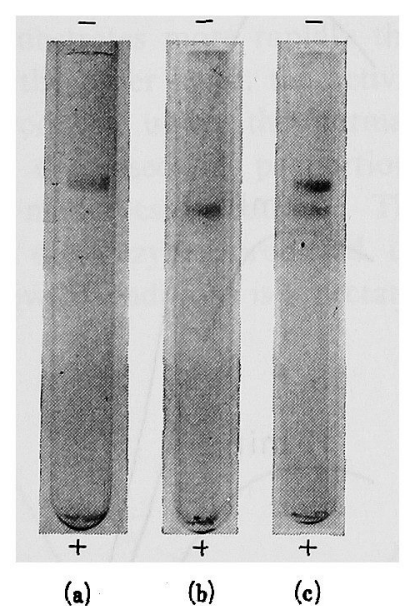

FIG. 3. Sodium Dodecyl Sulfate Polyacrylamide Gel Electrophoretic Patterns of Two Pectolytic Enzymes. (a), the pectolytic enzyme formed under normal growth conditions; (b), the pectin lyase induced by nalidixic acid; (c), the mixture of two enzymes.

has been purified approximately 40 -fold with $89 \%$ yield. It was almost homogeneous on SDS polyacrylamide gel electrophoresis as shown in Fig. 3a.
Properties of the enzyme

Molecular weight. The molecular weight of the enzyme was determined to be approximately 36,000 to 38,000 by the Andrews' gel filtration method $^{23)}$ and by the method of SDS polyacrylamide gel electrophoresis ${ }^{24}$ ) (Figs. 4, 5). This value differed significantly from that of the pectin lyase induced by nalidixic acid $(28,000$ to 32,000$){ }^{16)}$ In fact, the mixture of two enzymes gave two bands on SDS polyacrylamide gel electrophoretic analysis (Fig. 3c).

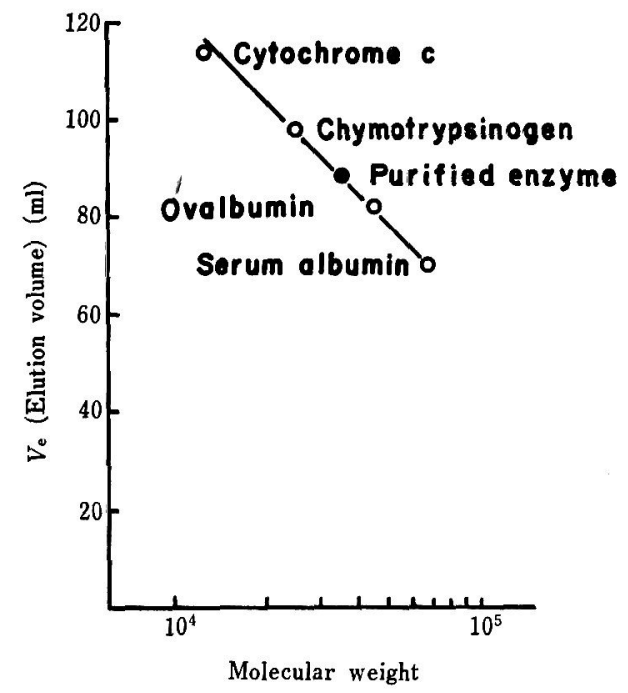

FIG. 4. Determination of Molecular Weight by Gel Filtration.

The purified enzyme and marker proteins were applied on a Sephadex G-75 column $(120 \mathrm{~cm} \times 1.3 \mathrm{~cm})$ and eluted with $0.5 \mathrm{M} \mathrm{KCl}$ in $0.05 \mathrm{M}$ Tris-(hydroxymethyl) aminomethane- $\mathrm{HCl}$ buffer (pH 8.2). The molecular weights of the marker proteins are for serum albumin, 67,000 ; for ovalbumin, 45,000 ; for chymotrypsinogen, 25,000 ; and for cytochrome c, 12,500 . 


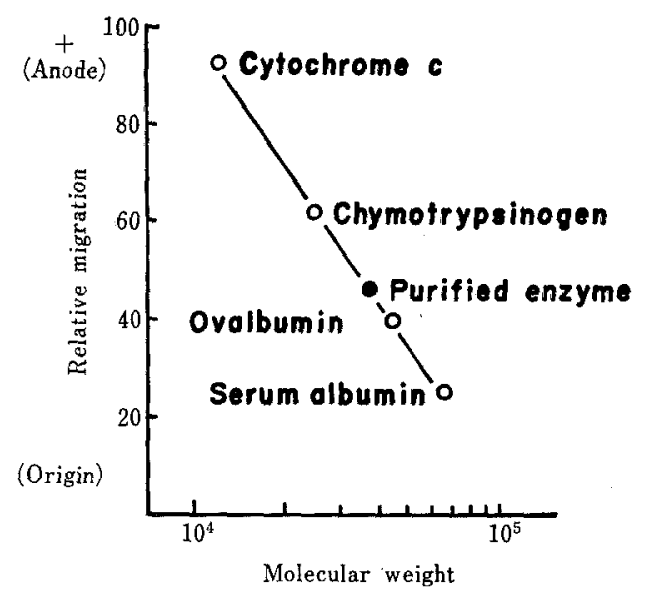

Fro. 5. Determination of Molecular Weight of the Purified Enzyme by Sodium Dodecyl Sulfate Polyacrylamide Gel Electrophoresis.

The conditions of electrophoresis were the same as in Fig. 3. The same marker proteins as in Fig. 4 were used. The relative migration of proteins is expressed as the ratio of distance of migration of a particular protein to that of bromophenol blue.

Effect of $\mathrm{pH}$ on pectate lyase activity. The effect of $\mathrm{pH}$ on the activity of pectate lyase is shown in Fig. 6. When pectic acid was used as substrate, the optimum pH was 9.0 to 9.2 . This relatively high value of optimum $\mathrm{pH}$ is in good agreement with the reported $\mathrm{pH}$

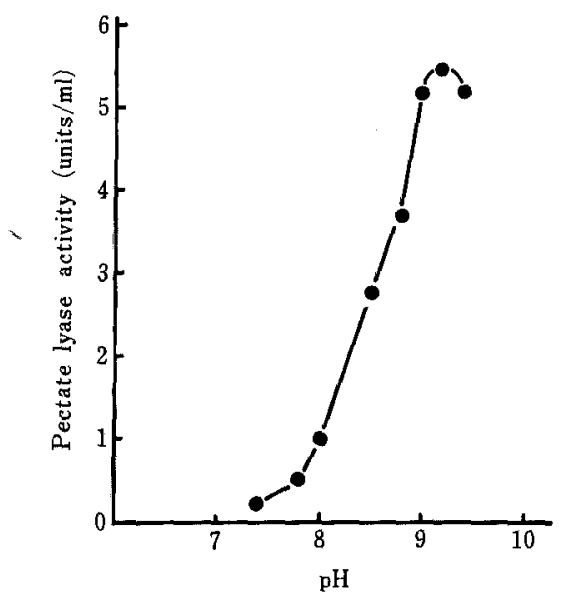

FIG. 6. Effect of $\mathrm{pH}$ on Activity of Pectate Lyase. Different $\mathrm{pH}$ of $0.05 \mathrm{M}$ Tris(hydroxymethyl)aminomethane- $\mathrm{HCl}$ buffer in reaction mixture was used to assay the pectate lyase activity with pectic acid as substrate. optima of the pectate lyases of other bacteria. In contrast, the optimum $\mathrm{pH}$ of the pectin lyase induced by nalidixic acid was about 8.0 to 8.2 as reported previously.

Enzymatic formation of $U V$-absorbing compounds from pectin. The changes in the $a b$ sorption spectrum of the reaction mixture during the incubation of the purified enzyme with pectic acid are shown in Fig. 7. As shown, the reaction products had the absorption maximum at $230 \mathrm{~nm}$ which is the same as that of 4,5-unsaturated galacturonides. Also, the products with the same absorption spectrum were obtained when pectin was used as the substrate.

To confirm the formation of 4,5-unsaturated compounds, the enzymatic products were reacted with thiobarbituric acid according to the method of Weissbach and Hurwitz. ${ }^{25}$

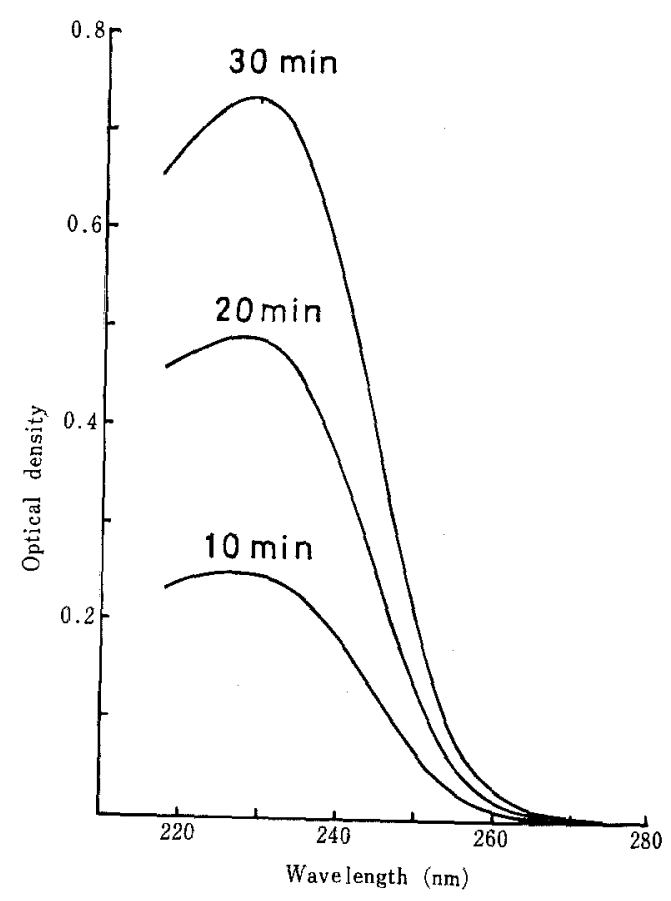

Fig. 7. Enzymatic Formation of UV-absorbing Compounds from Pectic Acid.

Reaction mixture was incubated at $30^{\circ} \mathrm{C}$. At indicated time, a portion of the reaction mixture was withdrawn, treated at $90^{\circ} \mathrm{C}$ for $10 \mathrm{~min}$, and the absorbancy was recorded. 
When the enzymatic products were reacted with thiobarbituric acid, pink color developed which had the absorption maximum around $550 \mathrm{~nm}$. This result is in agreement with the observation by Albersheim et al. ${ }^{1}$ Thus, it is clear that this enzyme catalyzes the cleavage of pectic acid or pectin by the trans-eliminase ("lyase") reaction.

Degradation of pectin, methoxylated pectic acid and pectic acid by the purified enzymes. The activities of purified two enzymes, the pectin lyase induced by nalidixic acid and the pectolytic enzyme formed under the normal growth conditions, toward pectin and pectic acid were examined. The pectin lyase attacked pectin but not pectic acid as reported previously. ${ }^{16)}$ In contrast, the latter enzyme attacked pectic acid more rapidly than pectin.

To examine the subatrate specificity in detail, pectic acid was methyl-esterified to various degrees and tested for their susceptibilities to the purified enzymes. As shown in Fig. 8, the pectin lyase attacks methylesterified substrates more rapidly than pectic acid. On the other hand, the activity of the enzyme produced under the normal growth conditions decreased in proportion to the degree of methyl-esterification. Thus, it is clear that the enzyme produced under the normal growth conditions is a pectate lyase.

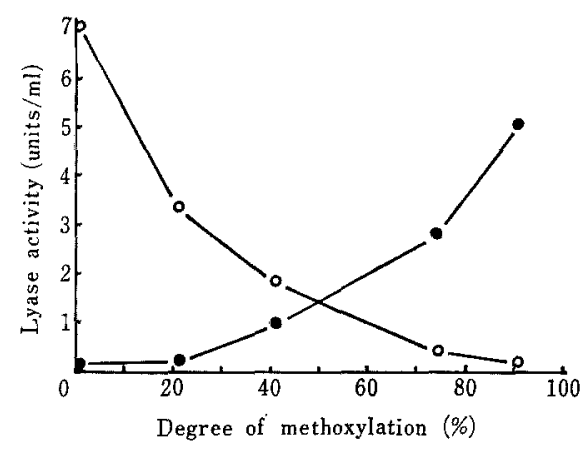

Fig. 8. Degradation of Methyl-esterified Substrates by Two Pectolytic Enzymes.

$\mathrm{O}-\mathrm{O}$, the pectolytic enzyme formed under normal growth conditions; $-\bullet$, the pectin lyase induced by nalidixic acid.
The mode of cleavage, terminal or random, can be determined by the simultaneous measurements of viscosity reduction and the extent of cleavage of the substrate. The endopectate lyase of Bacillus polymixa caused $50 \%$ reduction in relative viscosity of pectic acid when only about $2 \%$ of the glycosidic bonds were cleaved, ${ }^{10,11)}$ whereas the exo-pectate lyase from Clostridium multifermentans cleaved $22.5 \%$ of the glycosidic bonds of pectic acid when $50 \%$ reduction in viscosity occurred. ${ }^{5}$ ) As shown in Fig. 9, Erwinia pectate lyase caused $50 \%$ reduction in relative viscosity of pectin when $2 \%$ of the glycosidic bonds were cleaved. These results strongly suggested that the Erwinia pectate lyase attacks the polymer chain in random manner.

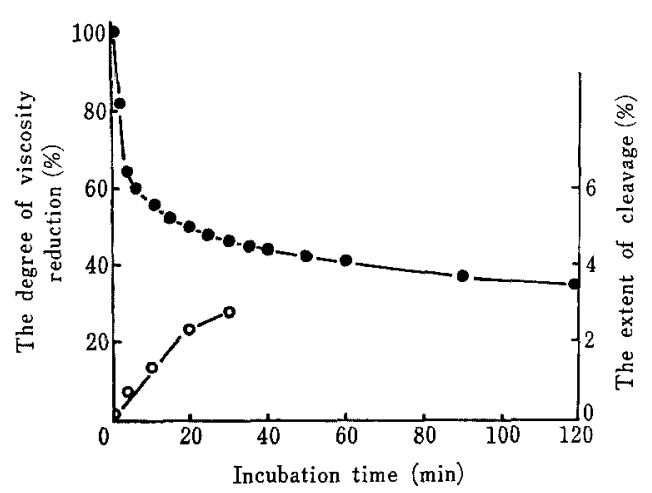

FIG. 9. Relationship between Viscosity Reduction and Cleavage of Glycosidic Bonds.

- , degree of viscosity reduction; $\bigcirc-0$, extent of cleavage.

Further evidence for such a mode of cleavage is shown by the column chromatographic analysis of the reaction products. As shown in Fig. 10, pectic acid was degraded to several oligouronides of heterogeneous size. When pectic acid was treated with a small amount of the enzyme, oligogalacturonides of higher molecular weights appeared soon after the start of the reaction and their concentrations decreased with time with a concomitant appearance of lower oligouronides (data not shown). These results support the random rather than the terminal degradation. 


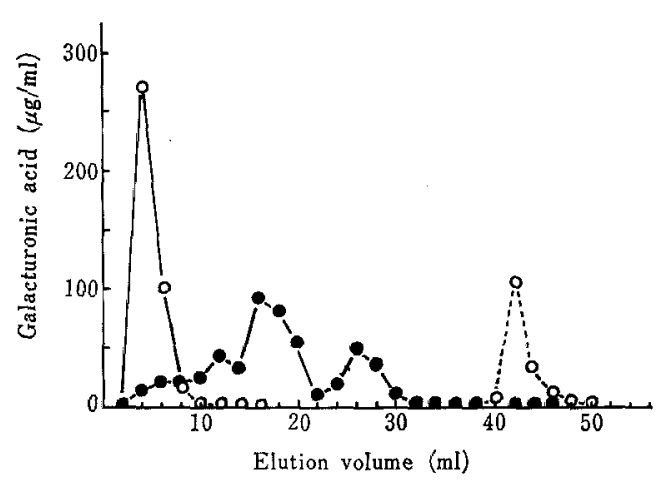

FIG. 10. Elution Profiles of Degradation Products from Pectic Acid by Pectate Lyase on Sephadex G-15 Column Chromatography.

- - with enzyme treatment; $\bigcirc-0$, without enzyme treatment; $\bigcirc--O$, free galacturonic acid standard.

Effects of cations on the pectate lyase activity. The effects of various cations on the pectate lyase activity were tested with pectic acid as the substrate. As shown in Table II, calcium was the only cation which had a marked stimulating effect on the enzyme activity.

Table II. EFFect of Cations and EDTA on the Pectate Lyase Activity

\begin{tabular}{lc}
\hline & Activity $(\%)$ \\
\hline $\mathrm{Control}^{+}\left(10^{-3} \mathrm{M}\right)$ & 100 \\
$\mathrm{~K}^{+}\left(10^{-3} \mathrm{M}\right)$ & 100 \\
$\mathrm{Mg}^{2+}\left(10^{-3} \mathrm{M}\right)$ & 100 \\
$\mathrm{Sr}^{2+}\left(10^{-3} \mathrm{M}\right)$ & 100 \\
$\mathrm{Ca}^{2+}\left(10^{-3} \mathrm{M}\right)$ & 100 \\
$\mathrm{Ni}^{2+}\left(10^{-3} \mathrm{M}\right)$ & 1050 \\
$\mathrm{Mn}^{2+}\left(10^{-3} \mathrm{M}\right)$ & 37 \\
$\mathrm{Ba}^{2+}\left(10^{-3} \mathrm{M}\right)$ & 27 \\
$\mathrm{Co}^{2+}\left(10^{-8} \mathrm{M}\right)$ & 7 \\
$\mathrm{Hg}^{2+}\left(10^{-3} \mathrm{M}\right)$ & 0 \\
$\mathrm{EDTA}^{\left(10^{-3} \mathrm{M}\right)}$ & 0 \\
\hline
\end{tabular}

Other cations such as sodium, potassium, magnesium, and strontium had no effect on the pectate lyase activity. On the other hand, inhibition was shown by cobalt, mercuric, nickel, manganese, and barium ions. The addition of $10^{-3} \mathrm{M}$ of ethylenediaminetetraacetate (EDTA) to the control reaction mixture completely inhibited the reaction. In contrast, most of the divalent cations stimulated the activity of the pectin lyase by 15 to $25 \%$ and EDTA did not show any inhibitory effect, as reported previously. ${ }^{16)}$

Stability of the pectate lyase. The enzyme was quite stable between $\mathrm{pH} 7.0$ and 8.5 at $30^{\circ} \mathrm{C}$ and no appreciable loss of activity was observed under these conditions for $36 \mathrm{hr}$. The optimal temperature for the enzyme activity was $35^{\circ} \mathrm{C}$. Heating the enzyme solution at $50^{\circ} \mathrm{C}$ for $10 \mathrm{~min}$ caused $50 \%$ loss of the activity.

\section{DISCUSSION}

Erwinia aroideae (AMS 6082) produced an inducible extra-cellular pectolytic enzyme when grown in the presence of pectin or pectic acid. The enzyme was purified 40 -fold from the culture fluid. The purified preparation was almost homogeneous on SDS-polyacrylamide gel electrophoresis. Pectic acid was degraded rapidly by the enzyme and pectin was attacked in inverse proportion to the degree of methoxylation of the substrate. At $50 \%$ reduction in the viscosity of the pectin substrate, only $2 \%$ of the glycosidic bonds were cleaved. The reaction products had a strong absorption peak at $230 \mathrm{~nm}$ and they reacted with thiobarbituric acid. These results demonstrate that the pectolytic enzyme excreted during normal growth is an endo-pectate lyase. The optimum $\mathrm{pH}$ of the pectate lyase was about 9.0 to 9.2 . The molecular weight of the enzyme was determined to be approximately 36,000 to 38,000 . This value is somewhat higher than those of endo-pectate lyase from $E$. carotovora $(31,000)^{26)}$ and E. chrysanthemi $(30,000$ to $32,000)^{27)}$ and that of endo-pectin lyase from Aspergillus sojae $(32,000){ }^{281}$

As reported previously, ${ }^{16)}$ when the same organism was treated with the inhibitors of DNA synthesis (nalidixic acid, Mitomycin C, Bleomycin, or UV irradiation), an endo-pectin lyase was produced concomitantly with the synthesis of bacteriocins. This endo-pectin lyase was purified and characterized. ${ }^{16)}$ This enzyme activity was not measurable in the 
culture fluid of normal growth, since the pectolytic activity of the fluid was completely inhibited by EDTA, which is a good inhibitor for the pectate lyase but not for the pectin lyase. Apart from the differences in substrate specificity and metal requirement, these two enzymes differed in molecular weights (pectin lyase, 28,000 to 32,000 ), $\mathrm{pH}$ optima (pectin lyase, 8.0 to 8.2 ) and inducibilities (no requirement of pectin or pectic acid for the induction of pectin lyase and no requirement of DNA inhibitors for the induction of pectate lyase, and vice versa).

Acknowledgement. This investigation was supported in part by a Grant for Scientific Research to H.T. (056023) from the Ministry of Education, Science and Culture.

\section{REFERENCES}

1) P. Albersheim, H. Neukom and H. Deuel, Helv. Chim. Acta, 43, 1422 (1960).

2) R. D. Edstrom and H. J. Phaff, I. Biol. Chem., 239, 2403 (1964).

3) R. D. Edstrom and H. J. Phaff, ibid., 239, 2409 (1964).

4) J. D. Macmillan and R. H. Vaughn, Biochemistry, 3, 564 (1964).

5) J. D. Macmillan, H. J. Phaff and R. H. Vaughn, ibid., 3, 572 (1964).

6) S. Nasuno and M. P. Starr, Biochem. J., 104, 178 (1967).

7) M. P. Starr and S. Nasuno, J. Gen. Microbiol., 46, 425 (1967).

8) S. Nasuno and M. P. Starr, Phytophathology, 56,
1414 (1966).

9) J. Preiss and G. Ashwell, J. Biol. Chem., 238, 1571 (1963).

10) C. W. Nagel and R. H. Vaughn, Arch. Biochem. Biophys., 93, 344 (1961).

11) C. W. Nagel and R. H. Vanghn, ibid., 94, 328 (1961).

12) M. P. Starr and F. Moran, Bacterial. Proc. Abstr., $1961,116$.

13) M.P. Starr and F. Moran, Science, 135, 920 (1962).

14) H. Tomizawa and H. Takahashi, Agric. Biol. Chem., 35, 191 (1971).

15) S. Kamimiya, K. Izaki and H. Takahashi, ibid., 36, 2367 (1972).

16) S. Kamimiya, T. Nishiya, K. Izaki and H. Takahashi, ibid., 38, 1071 (1974).

17) M. Manabe, Nippon Nôgeikagaku Kaishi, 45, 195 (1971).

18) I. Hirota, J. Chem. Soc. Jpn, Industrial Chemistry Section, 63, 2194 (1960).

19) T. Tsuchida, K. Nakamura, Y. Fujii and $H$. Takahashi, Agric. Biol. Chem., 32, 1355 (1968).

20) C. Hatanaka, Nippon Nôgeikagaku Kaishi, 41, 448 (1967).

21) T. Bitter and H. M. Muir, Anal. Biochem., 4, 330 (1962).

22) C. H. Lowry, N. J. Rosenbrough, A. L. Farr and R. J. Randall, J. Biol. Chem., 100, 385 (1933).

23) P. Andrews, Biochem. J., 91, 222 (1964).

24) K. Weber and M. Osborn, J. Biol. Chem., 244, 4406 (1969).

25) A. Weissbach and J. Hurwitz, ibid., 234, 705 (1959).

26) M. A. Mount, O. F. Bateman and H. G. Basham, Phytopathol., 60, 924 (1970).

27) A. Garibaldi and D. F. Bateman, Phytopathol. Mediter., 9, 136 (1970).

28) S. Ishii and T. Yokotsuka, Agric. Biol. Chem., 36, 146 (1972). 